\title{
Home Environment Strategy in Stimulating Children's Early Reading Skill Toward the Era of Information Technology
}

\author{
Ismaniar $^{1, *}$ \\ ${ }^{1}$ Department of Non-Formal Education, Faculty of Education, Universitas Negeri Padang, Padang, Indonesia \\ *Email: ismaniar.js.pls@fip.unp.ac.id
}

\begin{abstract}
Acquiring knowledge and technology is a must for those who want to survive in the era of information technology. The process of acquiring knowledge and technology is highly associated with language skills, especially reading. The role of the family is needed in preparing children's early reading skill to overcome the challenges of information technology era. However, with numerous problems in life and the lack of understanding, family is not able to play their role and stimulate their children optimally. One of the strategies to improve home environment in preparing the children towards the era of information technology is through implementation of home-based environmental print model.
\end{abstract}

Keywords: roles, home environment, challenge, era, technology, information

\section{INTRODUCTION}

In the era of information, one needs to be familiar with the information technology as almost every part of human life have been immensely associated with technology, from work, education, entertainment, and even daily necessities. Everything is related to the outcome of science and information technology. Thus, those who are unable to recognize the importance of acquiring information technology will be foreigner in life.

The tremendous challenges to survive in the era of information need early preparation and involvement from many sides. According to Ki Hajar Dewantoro, three education centers are the parties which take roles in developing excellent human sources. The term is referred to family, school, and society. The three parties take roles and place synergic cooperation to provide effective condition in the process of developing excellent human sources.

From the three roles, parents need to realize that family or home environment takes the foremost role. Home environment is irreplaceable in any condition because the early development of a child in terms of knowledge, behavior, and skills begin from home. Hence, for this reason, parents should be aware of and responsible for their role in stimulating their children's development.

Though parents take the main role, in reality, not all parents can execute their role perfectly. There are at least two factors affecting them; financial problem and the lack of understanding about the role of PAUD institutions. The high financial needs of family members that must be taken care of make parents spend no opportunities with their children. This commonly happens nowadays where parents are too busy with their job outside the home. As for the second problem, some parents have mistaken the role of PAUD institutions due to their lack of understanding. As a result, parents only hand over their children and pay some amount of money to the institution.

As explained above, such a problematic situation can be solved with solutions. One of the solutions that the writer provided here to improve the role of the home environment in preparing children towards the era of information is the home-based environmental print model.

\section{THEORETICAL FRAMEWORK}

\subsection{The essence of the information technology era}

The era of information technology is an interesting topic to be chosen in many meetings in recent years. The term itself is derived from two literal words. Technology, in general, is defined as a development of application or tools in the form of machine, material or process to help human conducting their works and solve their problems. Meanwhile, information generally means an outcome of a process or manipulation that holds knowledge value for the user. So, the definition of information technology is technology used to process data, arrange, organize, and acquire data manipulation to produce accurate and qualified information.

To get a deeper understanding of the definition, we can refer to several experts' opinions. McKeown[1] explained that information technology refers to every form of technology used to make, store, replace and utilize information. Williams \& Sawyer[2] defined information 
technology is a collaborative technology which combines computer and high-speed communication platform carrying data, voice, and video. Furthermore, Laudon \& Laudon[3] stated that information technology is a tool to overcome a change. Change, in this context, refers to information change which is processed and restored in computer. Brown, DeHayes, Hoffer, Martin, \& Perkins[4] pointed out that information technology is a combination of hardware and software in processing, storing and distributing information.

Based on the experts' arguments above, we can refer to the era of information as the era where the various aspect of human life relies on the innovation and invention of information technology. Data is processed, organized, stored and relayed to produce accurate and valid information. When someone shows off his existence in the era of information technology, mastering knowledge of information technology is a must. It is not simply given away and needs some skills. One of the skills needed in comprehending information technology is language skills, especially reading skill. Reading skill is a tool which enables a person to reach his goals. Printed and online media are multifaceted. Each of them provides various information that can be learned and taken as a solution when facing problem in reading.

\subsection{The Essence of Reading Skill}

It is undeniable that reading skill is pivotal and functional in life. However, people understand about its meaning may not similar each other as people have different point of view and knowledge. According to An[5], reading basically is a process to understand the meaning of writing. Reading includes 1) identification of letters 2) sound of letters 3 ) meaning and contextual meaning of a narrative. In brief, reading is a complex activity associated with various skills. Those activities include recognizing letters and words, connecting them with sound and meaning and concluding the reading.

When someone has good ability in reading, it gives him benefits from all sort of information, both printed and online. In addition, it helps when learning science and technology without relying much on other people. Nonetheless, due to its complexity, mastering reading skill and making it a habit is not an easy task. In other words, this reading skill needs to be stimulated since an early age. Early childhood education expert, Montessori cited in Santrock argued that children aged 4-5 years old are old enough to be taught reading and writing. Montessori also added that reading and writing can actually be fun for children. This argument is supported by Mary Leonhart[6], who stated that reading skill is important. Some advantages from reading in early age are 1) children's pleasure when reading help them to attain good reading skill and spend their days positively on reading 2) children's fond of reading makes them store advanced vocabularies which support their speaking and writing ability, as well as their understanding of difficult ideas. 3) Reading provides children a wide range of knowledge which helps their learning activities 4) reading plants affection in children 5) children who enjoy reading are able to develop creativity 6) children who enjoy reading always have solution or alternative when coping with problems.

With these premises explained above, it should be noted that reading is a complex activity that holds important values in life and needs to be stimulated since early age.

\subsection{The Essence of Home Environment}

Darsono[7] defined environment as things and conditions. It includes human and all their activities, in which they influence each other's sustainability and prosperity. According to Ismaniar, Jamaris, \& Wisroni[8], [9] family is a group of people consists of family head and family members engaged in married relationship or live in one place, holds collective rules, influences each other and possess clear goal and program. From the definitions of the two words, home environment is all situations and conditions in the forms of subjects and activities occurred in the family and influence the interaction of the members. Home is the first and foremost environment for children's development as well as their reading skill. The family role is irreplaceable. Though in practice, for some reasons, family is assisted by other parties in conducting their responsibility, their role does not vanish. Ismaniar \& Sunarti[10] explained that family has several functions; financial function, social function, educational function, psychological function, protection function, and reproduction function. Educational function is one of the main functions of a family. Family is obliged to provide education to their members especially children to assist their age development and enable them to adapt to their environment.

\subsection{Home-Based Environmental Print Model}

Home-based environmental print model is an environmental design conducted in means to stimulate children's early reading skill. This model is inspired by Neumann, Hood, Ford, \& Neumann[11] model which was published on Sage Publications entitled "The Role of Environmental Print in Emergent Literacy". In her research, several examples of environmental prints are used in stimulating children, such as street signs, candy wraps, the label on peanut butter and $\mathrm{K}$ as in Kmart.

Home-based environmental print model is an idea utilizing environment in the family or the surroundings of the house to conduct the activity. The idea of using home environment emerges in relation to the reality, which shows, from the children's side, that home environment is the dominant environment. Besides, family is the first and foremost environment that influences children's development. In the daily activity, children spend most of their time at home. As for parents, let alone their struggle with their job, the place they go to the most is still home. 
Therefore, with home-based environmental print, even though parents have limited time to stimulate their children's early reading skill, it still can be conducted directly or indirectly. Seen from the financial side, homebased environmental print spends no expense, much time and particular resource to make it effective and efficient

\section{DISCUSSION}

The rapid development of information technology is undefeated. The existence of information technology has faded away from the boundaries of countries in term of the flow of information. No country has been able to prevent the flow of information from or into the other countries, because boundary has no place in the virtual world of the computer. Technological implementation such as LAN, WAN, Global Net, Intranet, Internet, and Extranet are massively developed, spread out and civilize in society. The era of information technology provides diverse advancement and facilities for users.

Place, time, cost and recourse no longer become obstacles in doing activities in the era of information technology, yet the challenge for the recent generation is to conquer the technology itself. If they are able to adapt to the development of technology, they will live effectively and efficiently. On the other hand, if they are unable to adapt to the development, they will live harder as they need to rely on others' help. As stated by Haag \& Keen in Kadir \& Triwahyuni[12], information technology is a set of device to help human with their activities by conducting several processes in relation to the information.

The development of information technology is identical to the development of other features and applications. In the effort to conquer the information technology, people are faced with two options, either to conquer it by themselves or use other's service. The two conditions carry different risks. If one chooses to conquer it by himself or selftaught, from the financial side, it takes efficient expense as the applications and features are available online and selftaught. To achieve the first condition, various supported skills are needed; one of them is reading skill. Meanwhile, if one chooses to use other or institution's service, the consequence is the expensive cost.

Based on that reasoning, family is responsible to take the role in preparing their children showing their existence in the era of information technology. The implementation of home environment in preparing children will create a ready generation to overcome the challenges of era preventively, effectively and efficiently. Mastering language skills, particularly reading skill, takes an important role in conquering the information technology. Reading needs to be carried out habitually as every opportunity and place can be the sources for self-upgrade. Furthermore, reading is a complex activity that needs to be accustomed since an early age [13]. It is not a wise decision when the parent's role in stimulating children is fully handed over to school or other parties. Thus, homebased environmental print is an effective design to educate parents in optimally utilizing home environment

\section{CONCLUSION}

The era of information and technology provides numerous convenience, effectiveness, and accessibility in almost every part of life. Those who are able to acquire information technology will gain benefits and survive. On the other hand, those who are unable to acquire it will be overladen with the development. Reading skill is one of the solutions to conquer the challenges of the era in the costly expense of learning the technology. Family as the main responsible agent of education needs to prepare their children since an early age. One of the solutions to help in preparing children early reading skill is the implementation of home-based environmental print

\section{REFERENCES}

[1] P. G. McKeown, Information Technology and the Networked Economy. Boston, MA, United States: Course Technology, 2002.

[2] B. K. Williams and S. C. Sawyer, Using Information Technology: A Practical Introduction to Computers \& Communications, 9th ed. New York: McGraw-Hill, 2010.

[3] K. C. Laudon and J. P. Laudon, Management Information Systems: Managing the Digital Firm, 12th ed. New Jersey: Prentice Hall, 2010.

[4] C. V. Brown, D. W. DeHayes, J. A. Hoffer, W. E. Martin, and W. C. Perkins, Managing Information Technology, 7th ed. United Kingdom: Pearson Education Limited, 2013.

[5] S. An, "Schema Theory in Reading," Theory Pract. Lang. Stud., vol. 3, no. 1, pp. 130-134, 2013.

[6] I. Ismaniar, "Optimalisasi Peran Keluarga dalam Stimulasi Kemampuan Membaca Awal Anak Melalui Pendekatan Environmental Print," E-TECH J. Ilm. Teknol. Pendidik., vol. 6, no. 2, pp. 1-8, 2018.

[7] V. Darsono, Pengantar Ilmu Lingkungan. Yogyakarta: Penerbitan Universitas Atma Jaya, 1995.

[8] I. Ismaniar, J. Jamaris, and W. Wisroni, "Improving Early Reading Ability Using Environmental Print Approach in the Family," in 1st Non Formal Education International Conference (NFEIC 2018), 2019, vol. 293, no. Nfeic 2018, pp. 52-55.

[9] I. Ismaniar, J. Jamaris, and W. Wisroni, "Pentingnya Pemahaman Orang Tua Tentang Karakteristik Pembelajaran AUD dalam Penerapan Model Environmental Print Berbasis Keluarga," Kolok. J. Pendidik. Luar Sekol., vol. 6, no. 2, pp. 93-100, 2018.

[10] I. Ismaniar and V. Sunarti, Buku Ajar Pelatihan Parenting. Padang: Penerbit Jurursan Pendidikan Luar Sekolah Fakultas Ilmu Pendidikan Universitas Negeri Padang, 2018. 
[11] M. M. Neumann, M. Hood, R. M. Ford, and D. L. Neumann, "The Role of Environmental Print in Emergent Literacy," J. Early Child. Lit., vol. 12, no. 3, pp. 231-258, 2012.

[12] A. Kadir and T. C. Triwahyuni, Pengantar Teknologi Informasi Edisi Revisi. Yogyakarta: Andi Offset, 2013.

[13] M. Leonhardt, 99 Cara Menjadikan Anak Anda Keranjingan Membaca, 4th ed. Bandung: Kaifa, 2001. 